\title{
On the Position of Thoracic Organs in Macacus cyclopsis
}

\author{
By \\ Mikio Naruse \\ First Department of Anatomy, Faculty of Medicine \\ Nagasaki University \\ (Director: Prof. Dr. Jun-ichiro Sa to h)
}

In a previous report, K. C. L i n (1955) of this department presented the results of his studies on the position of abdominal organs in Macacus cyclopsis. In the present study, the major organs in the thoracic cavity were investigated. The purpose of this work was to determine the most common condition, in other words the so-called basic normal condition in Macacus cyclopsis by the investigation of a comparatively large number of cases. An additional reason for this study is that hardly any investigations of such nature have been done on primates.

\section{Material and Method}

The material consisted of 20 bodies ( 11 male, 9 female) of adult Macacus cyclopsis collected by Prof. Satoh. These animals after capture and strangulation had been immediatly fixed by the injection of $10 \%$ formalin solution into the femoral artery. All cases with deformity or distortion were excluded.

For this study, the body was first fixed to a dissection table so as to prevent change of position. As each organ was exposed and removed, their borders were projected onto a single surface and diagrams prepared by a delineator. Measurements were taken on these projected diagrams.

As base points for measurements, the midpoint of the upper edge of the 12th thoracic vertebra in back and the lower tip of the sternum in front were used to measure the height while the distance to each side was measured from the midline.

Although only adult animals had been used in this study, individual differences in size of the animals are evident. Moreover, 
since the use of the actual measurements would be of little use in the comparison with man, the actual values were converted into ratio values. Measurements based upon the 12 th vertebra-were divided by the distance between the upper edge of the 1st thoracic vertebra to the upper edge of the $12 \mathrm{th}$ vertebra and the values based upon the lower tip of the sternum were divided by the distance between the midpoint of the upper edge of the sternum and the lower tip of the sternum while the distance to each side of the midline was divided by the transverse diameter of the thorax at the level midway between the upper edge of the 1st thoracic vertebra and the upper edge of the 12th thoracic vertebra.

In the comparison with man, primarily the findings for human fetus obtained by myself with the same method of study were used.

\section{Findings}

\section{Position of the base points for measurement}

Before presenting the findings for the various organs, the relation of the respective base points for measurement to the total abdominal length will be discussed. The total abdominal length, i.e., the average distance from the upper edge of the pubic symphysis to the upper edge of the sternum, was $31.9 \mathrm{~cm}$. The average distance from the upper edge of the pubic symphysis to the anterior base point, i. e., the lower tip of the sternum, was $23.8 \mathrm{~cm}$, while the average distance to the posterior base point, i. e., the upper edge of the 12 th thoracic vertebra, was $20.7 \mathrm{~cm}$.

In relation to an abdominal length of 100 , the ratio of the distance from the upper edge of the pubic symphysis to the respective base points is approximately 75 to the lower tip of the sternum and 65 to the upper edge of the 12th thoracic vertebra (table 1).

For information, the distance from the upper edge of the 12th thoracic vertebra to the upper edge of the other thoracic vertebrae was measured which revealed the height of each vertebral body to be approximately $1 \mathrm{~cm}$. Therefore, it may be assumed that the distance between the upper edge of the 12 th thoracic vertebra and the upper edge of the 1st lumbar vertebra, which had been used as the base point by K. C. L i $n$ in his study of the position of the abdominal organs, also is approximately $1 \mathrm{~cm}$. (table 2 ). 


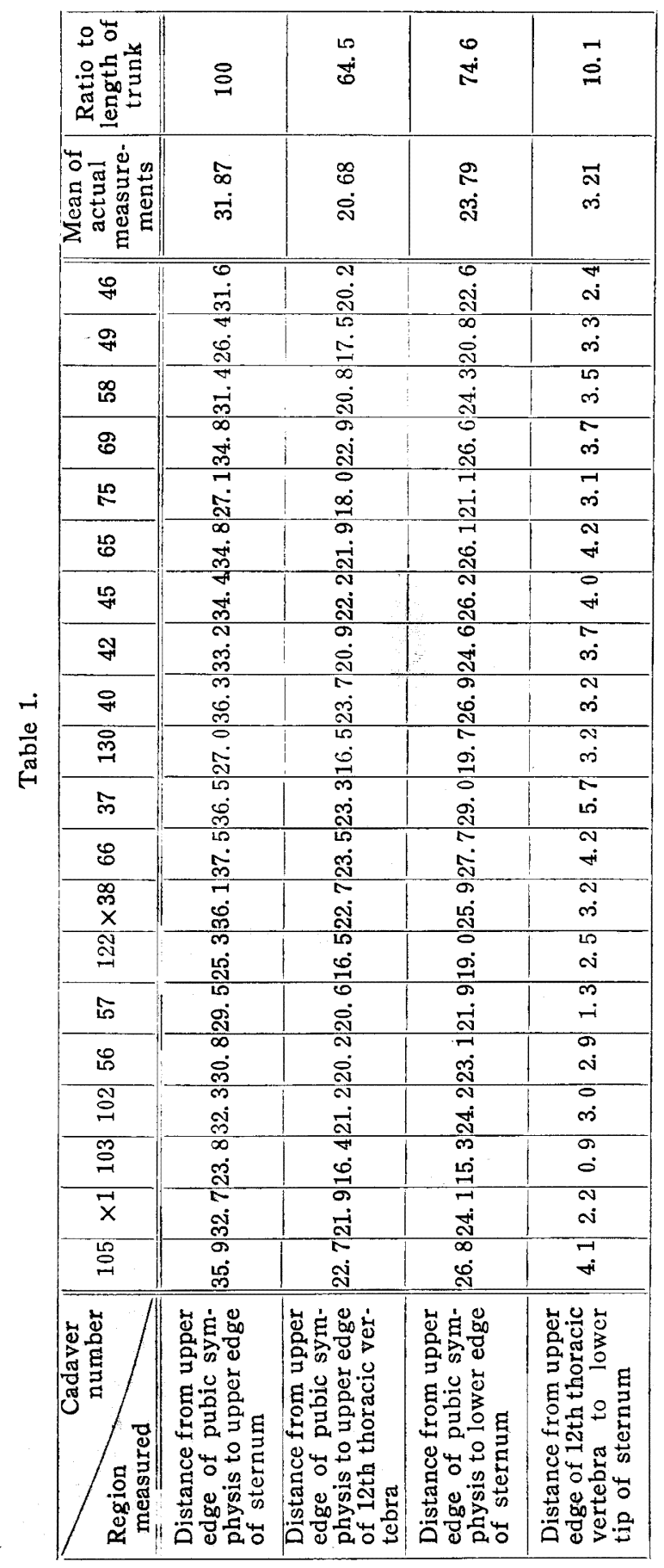


Table 2. The height from upper edge of 12 th thoracic vertebra to upper edge of other thoracic vertebrae.

\begin{tabular}{|c||c|c|c|c|c|c|c|}
\hline \hline $\begin{array}{c}\text { Region } \\
\text { measured number }\end{array}$ & 105 & $\times 1$ & 103 & 102 & 56 & $\begin{array}{c}\text { Mean of actual } \\
\text { measurements }\end{array}$ & $\begin{array}{c}\text { Ratio } \\
(\%)\end{array}$ \\
\hline 1st thoracic vertebra & 12.7 & 11.0 & 7.6 & 10.5 & 10.4 & 10.4 & 100 \\
\hline 2nd thoracic vertebra & 11.9 & 10.4 & 7.1 & 9.6 & 9.6 & 9.7 & 93.2 \\
\hline 3rd thoracic vertebra & 10.9 & 9.5 & 6.7 & 8.7 & 8.8 & 8.9 & 85.5 \\
\hline 4th thoracic vertebra & 9.8 & 8.5 & 6.0 & 7.9 & 8.0 & 8.0 & 76.9 \\
\hline 5th thoracic vertebra & 8.6 & 7.7 & 5.4 & 7.1 & 7.2 & 7.2 & 69.2 \\
\hline 6th thoracic vertebra & 7.6 & 6.8 & 4.6 & 6.3 & 6.3 & 6.3 & 60.5 \\
\hline 7th thoracic vertebra & 6.5 & 5.9 & 3.9 & 5.5 & 5.4 & 5.4 & 51.9 \\
\hline 8th thoracic vertebra & 5.4 & 4.9 & 3.2 & 4.4 & 4.7 & 4.5 & 43.2 \\
\hline 9th thoracic vertebra & 4.2 & 3.9 & 2.5 & 3.6 & 3.6 & 3.5 & 33.6 \\
\hline 10th thoracic vertebra & 1.8 & 2.8 & 1.7 & 2.6 & 2.5 & 2.4 & 23.0 \\
\hline 11th thoracic vertebra & 1.3 & 1.4 & 1.0 & 1.5 & 1.2 & 1.2 & 11.5 \\
\hline
\end{tabular}

\section{Trachea (Table 3, 4)}

Measurements on the trachea include the position of the tip of the angle of bifurcation of the trachea, the position of entry of bronchi into the hilum on each side and the angle formed by the bronchi.

1) The position of the tip of the angle of bifurcation of the trachea measured from the upper edge of the 12 th thoracic vertebra was at an average height of $7.2 \mathrm{~cm}$ (converted value $65.5 \%$ ) and located $0.2 \mathrm{~cm}$ (converted value $2.4 \%$ ) to the right of the midline.

Its position in my study of Japanese fetus was at a height in the range of 75.8 to $82.9 \%$ with hardly any change with advancing gestational age while the distance from the midline was 2.9 to $4.3 \%$ to the right, the smaller values being found in the earlier stage of fetal development. Therefore, the tip of the angle of bifurcation of the trachea in Macacus cyclopsis is approximately 10 to $17 \%$ lower than in Japanese fetus. It also is closer to the midline than in human fetus, the ratio being closest to that in a 5-month-old fetus.

Measured from the lower tip of the sternum, its average height in Macacus cyclopsis was $3.9 \mathrm{~cm}$ (converted value $48.9 \%$ ). 
Table 3. Trachea

\begin{tabular}{|c|c|c|c|c|}
\hline \multirow[b]{2}{*}{$\begin{array}{l}\text { Region } \\
\text { measured }\end{array}$} & \multicolumn{2}{|c|}{$\begin{array}{l}\text { Measurements based on } \\
12 \text { th thoracic vertebra }\end{array}$} & \multicolumn{2}{|c|}{$\begin{array}{l}\text { Measurements based on } \\
\text { lower tip of sternum }\end{array}$} \\
\hline & $\begin{array}{l}\text { Mean of actual } \\
\text { measurements }\end{array}$ & Ratio & $\begin{array}{l}\text { Mean of actual } \\
\text { measurements }\end{array}$ & Ratio \\
\hline $\begin{array}{l}\text { Height of tip of angle of } \\
\text { bifurcation of trachea }\end{array}$ & 7.2 & 65.5 & 3.9 & 48.9 \\
\hline $\begin{array}{l}\text { Distance from midline } \\
\text { of tip of angle of bifur- } \\
\text { cation of trachea }\end{array}$ & 0.2 & 2.4 & & \\
\hline $\begin{array}{l}\text { Height of location of } \\
\text { entry of left bronchus } \\
\text { into hilum } \\
\text { (upper branch) }\end{array}$ & 6.5 & 59.1 & 3.2 & 40.5 \\
\hline $\begin{array}{l}\text { Height of location of } \\
\text { entry of left bronchus } \\
\text { into hilum } \\
\text { (lower branch) }\end{array}$ & 6.0 & 54.5 & 2.7 & 33.9 \\
\hline $\begin{array}{l}\text { Distance from midline } \\
\text { of location of entry of } \\
\text { left bronchus into hilum } \\
\text { (upper branch) }\end{array}$ & 1.2 & 14.5 & & \\
\hline $\begin{array}{l}\text { Distance from midline } \\
\text { of location of entry of } \\
\text { left bronchus into hilum } \\
\text { (lower branch) }\end{array}$ & 1.0 & 12.0 & & \\
\hline $\begin{array}{l}\text { Height of location of } \\
\text { entry of right bronchus } \\
\text { into hilum } \\
\text { (upper branch) }\end{array}$ & 7.1 & 64.5 & 3.7 & 46.7 \\
\hline $\begin{array}{l}\text { Height of location of } \\
\text { entry of right bronchus } \\
\text { into hilum } \\
\text { (middle branch) }\end{array}$ & 6.2 & 56.3 & 2.8 & 35.5 \\
\hline $\begin{array}{l}\text { Height of location of } \\
\text { entry of right bronchus } \\
\text { into hilum } \\
\text { (lower branch) }\end{array}$ & 5.8 & 52.7 & 2.5 & 31.5 \\
\hline $\begin{array}{l}\text { Distance from midline } \\
\text { of location of entry of } \\
\text { right bronchus into } \\
\text { hilum (upper branch) }\end{array}$ & 1.2 & 14.5 & & \\
\hline $\begin{array}{l}\text { Distance from midline } \\
\text { of location of entry of } \\
\text { right bronchus into } \\
\text { hilum (middle branch) }\end{array}$ & 1.3 & 15.7 & & \\
\hline $\begin{array}{l}\text { Distance from midline } \\
\text { of location of entry of } \\
\text { right bronchus into } \\
\text { hilum (lower branch) }\end{array}$ & 1.0 & 12.0 & & \\
\hline
\end{tabular}

In human fetus, it is in the range of 61.4 to $71.4 \%$ and the value decreases with advancing gestational age. Consequently, in Macacus cyclopsis, it is 12 to $20 \%$ lower than in human fetus and 


\begin{tabular}{|c|c|c|c|}
\hline 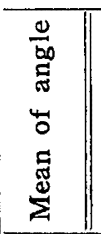 & $\begin{array}{l}10 \\
\stackrel{1}{m}\end{array}$ & $\overrightarrow{\mathrm{S}}$ & $\begin{array}{l}0 \\
\dot{0}\end{array}$ \\
\hline$\stackrel{2}{\circ}$ & $\dddot{m}$ & $\dddot{N}$ & 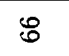 \\
\hline$\vec{x}$ & 악 & $\stackrel{\sigma}{\rightarrow}$ & 욤 \\
\hline in & $\vec{m}$ & $\stackrel{10}{10}$ & $\mathscr{F}$ \\
\hline స్ & 18 & สี & 5 \\
\hline$\stackrel{\cong}{\varrho}$ & 유 & $\vec{N}$ & $\overrightarrow{0}$ \\
\hline 总 & P & జ్ల & $\mathfrak{N}$ \\
\hline$\stackrel{\infty}{\infty}$ & $\stackrel{m}{\circ}$ & నิ & 냉 \\
\hline 电 & $\exists$ & 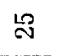 & 8 \\
\hline $\mathscr{8}$ & సิ & N & $\mathcal{F}$ \\
\hline$\hat{\infty}$ & $\stackrel{\infty}{\infty}$ & ஜ & $\stackrel{\infty}{\curvearrowright}$ \\
\hline \% & ले & $\infty$ & $\stackrel{2}{2}$ \\
\hline 8 & 7 & กิ & $\ddot{\theta}$ \\
\hline F & ల్లి & ల్ల & 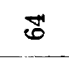 \\
\hline $\mathscr{8}$ & న్ల & $\ddot{m}$ & 88 \\
\hline $\mathscr{Z}$ & $\tilde{ల}$ & ล & 요 \\
\hline 88 & $\stackrel{8}{8}$ & $\overrightarrow{\mathrm{N}}$ & $F$ \\
\hline$\stackrel{10}{R}$ & gి & న & $\tilde{0}$ \\
\hline 8 & ల్ల & $m$ & $\mathscr{q}$ \\
\hline$\stackrel{\infty}{\circ}$ & กิ & $\approx$ & 8 \\
\hline F & $\exists$ & $\stackrel{\infty}{\sim}$ & 8 \\
\hline 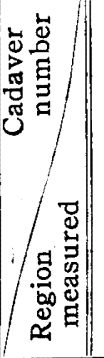 & 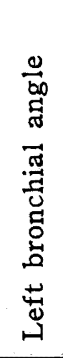 & 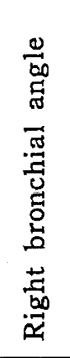 & 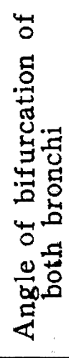 \\
\hline
\end{tabular}

closest to that of a fetus in the 10th month of gestation.

2) The height at which the left bronchus enters into the hilum, measured from the 12 th thoracic vertebra, was $6.5 \mathrm{~cm}$ for the upper branch and $6.0 \mathrm{~cm}$ for the lower branch, with converted values of $59.1 \%$ and $54.5 \%$ respectively. The respective distance from the midline was $1.2 \mathrm{~cm}$ and $1.0 \mathrm{~cm}$ or, in terms of converted values, $14.5 \%$ and $12.0 \%$.

This height in human fetus is $63.6 \%$ to $72.0 \%$ and the distance from the midline is $8.6 \%$ to $12.3 \%$ which indicates that, just as for the tip of the angle of bifurcation, its position is approximately $10 \%$ lower and 2 to $3 \%$ father lateral in Macacus cyclopsis than in human fetus.

Measured from the lower tip of the sternum, the height is at an average of $3.2 \mathrm{~cm}$ for the upper branch and $2.7 \mathrm{~cm}$ for the lower branch which, in terms of converted values, are $40.5 \%$ and $33.9 \%$ respectively. Compared with the range of $43.2 \%$ to $57.1 \%$ in human fetus, it is considerably lower in Macacus cyclopsis.

3) The height at which the right bronchus enters into the hilum measured from the 12 th thoracic vertebra is $7.1 \mathrm{~cm}$ for the upper branch, $6.2 \mathrm{~cm}$ for the middle branch and $5.8 \mathrm{~cm}$ for the lower branch which convert to $64.5 \%, 56.3 \%$ and $52.7 \%$ respectively. The position of the upper branch is slightly higher and the lower branch slightly lower than in the left bronchus. The distance from the midline is $1.2 \mathrm{~cm}$ for the upper branch, $1.3 \mathrm{~cm}$ for the middle branch and $1.0 \mathrm{~cm}$ for the 
lower branch which, in terms of converted values, are $14.5 \%, 15.7 \%$ and $12.0 \%$ respectively which is almost the same as in the case of the left bronchus.

The height in human fetus is $63.6 \%$ to $68.3 \%$ while the distance from the midline is $11.4 \%$ to $13.0 \%$. Therefore, its position in Macacus cyclopsis is slightly lower and farther lateral than in human fetus.

Measured from the lower tip of the sternum, the average height is $3.7 \mathrm{~cm}$ for the upper branch, $2.8 \mathrm{~cm}$ for the middle branch and $2.5 \mathrm{~cm}$ for the lower branch which in converted values is $46.7 \%$ for the upper branch, $35.5 \%$ for the middle branch and $31.5 \%$ for the lower branch which are approximately $8 \%$ lower than the range of 40.9 to $50.0 \%$ in human fetus.

4) The angle formed by the bronchi was an average of $61.6^{\circ}$ which is slightly less than the average value of $70^{\circ}$ reported by $\mathrm{Nozaki}$ for Japanese adults. The angle formed by each bronchus in relation to the midline is slightly greater on the left side, just as in man. The angle between the left bronchus and the midline was an average of $37.5^{\circ}$ while the angle formed by the right bronchus and the midline was $24.1^{\circ}$.

\section{Heart (Table 5)}

Measurements on the heart include the position of the upper border, lower border and both lateral edges.

1) The height of the upper border of the heart, measured from the $12 \mathrm{th}$ thoracic vertebra, was an average of $8.5 \mathrm{~cm}$ which in terms of converted values was $77.3 \%$ and the distance from the midline was 0 .

The height of the upper border of the heart in man is said to be much the same in adults and fetus, but in my study of human fetus, the converted value is $72.7 \%$ to $80.8 \%$ and the distance from the midline is from 0 to $7.7 \%$ with increasing distance from the midline with gestational age. Therefore, the height of the upper pole is not much different from that in Macacus cyclopsis being particularly close to that for 6 to 7 months old fetus while the distance from the midline is the same as that for 5-month-old fetus and closer to the midline than at any other month of gestation.

The height of the upper border of the heart measured from the 
Mikio Naruse

Table 5. Heart

\begin{tabular}{|c|c|c|c|c|}
\hline \multirow[b]{2}{*}{$\begin{array}{l}\text { Region } \\
\text { measured }\end{array}$} & \multicolumn{2}{|c|}{$\begin{array}{l}\text { Measurements based on } \\
12 \text { th thoracic vertebra }\end{array}$} & \multicolumn{2}{|c|}{$\begin{array}{l}\text { Measurements based on } \\
\text { lower tip of sternum }\end{array}$} \\
\hline & $\begin{array}{l}\text { Mean of actual } \\
\text { measurements }\end{array}$ & Ratio & $\begin{array}{l}\text { Mean of actual } \\
\text { measurements }\end{array}$ & Ratio \\
\hline Height of upper border & 8.5 & 77.3 & 5.2 & 65.4 \\
\hline $\begin{array}{l}\text { Distance from midline } \\
\text { of lowest point }\end{array}$ & $\begin{array}{ll}\text { right } & 2.9 \\
\text { left } & 0.4\end{array}$ & $\begin{array}{l}3.6 \\
0 \\
4.3\end{array}$ & & \\
\hline Height of lower border & 3.7 & 33.6 & 0.4 & 5.3 \\
\hline $\begin{array}{l}\text { Distance from midline } \\
\text { of lowest point }\end{array}$ & 1.3 & 15.7 & & \\
\hline $\begin{array}{l}\text { Height of point farthest } \\
\text { to left }\end{array}$ & 5.4 & 49.1 & 2.1 & 26.4 \\
\hline $\begin{array}{l}\text { Distance from midline } \\
\text { of point farthest to left }\end{array}$ & 2.5 & 30.1 & & \\
\hline $\begin{array}{l}\text { Height of point farthest } \\
\text { to right }\end{array}$ & 6.0 & 54.5 & 2.9 & 36.5 \\
\hline $\begin{array}{l}\text { Distance from midline } \\
\text { of point farthest to right }\end{array}$ & 1.9 & 22.9 & & \\
\hline
\end{tabular}

lower tip of the sternum is an average of $5.2 \mathrm{~cm}$ (converted value $65.4 \%$ ). The actual values in human fetus increase with gestational age, the converted values being in the range of $61.9 \%$ to $68.6 \%$, and hence the values for Macacus cyclopsis are similar to that of human fetus of about 8 months.

2) The height of the lower border of the heart measured from the 12 th thoracic vertebra is an average of $3.7 \mathrm{~cm}$ (converted value $33.6 \%)$. The distance from the midline is $1.3 \mathrm{~cm}(15.7 \%)$ to the left of the midline.

The height in human fetus is $30.3 \%$ in the 5th month and $37.0 \%$ in the 10 th month while the distance from the midline is in the range of $21.7 \%$ to $25.0 \%$. Therefore, the height does not differ very much from that in human fetus just as in the case of the upper border of the heart. Only the distance from the midline is different, being closer to the midline than in human fetus.

When measured from the lower tip of the sternum, the average value is $0.52 \mathrm{~cm}$ (converted value $5.3 \%$ ) in Macacus cyclopsis. It is 
only slightly above this base point for measurement, but in human fetus it is from $2.9 \%$ to $7.1 \%$ below this base point.

3) The position of the point farthest to the left as measured from the 12th thoracic vertebra is at an average height of $5.4 \mathrm{~cm}$ (converted value $49.1 \%)$ and $2.5 \mathrm{~cm}(30.1 \%)$ from the midline.

The height of this point in human fetus in the 5th month of gestation is $39.4 \%$ after which there is a gradual shift upward to $46.6 \%$ in the 10th month while the distance from the midline is in the range of $31.4 \%$ to $36.1 \%$. Hence, in the terminal stage of gestation, its position is slightly lower and slightly farther from the midline than in Macacus cyclopsis.

Measured from the lower tip of the sternum, it is at an average height of $2.1 \mathrm{~cm}(26.4 \%)$ in Macacus cyclopsis whereas in human fetus it is from $9.1 \%$ to $14.3 \%$, and thus its position is higher in Macacus cyclopsis just as it is when the 12th thoracic vertebra is used as the base point.

4) The height of the point farthest to the right, measured from the 12 th thoracic vertebra is an average of $6.0 \mathrm{~cm}(54.5 \%)$, and the distance from the midline is an average of $1.9 \mathrm{~cm}(22.9 \%)$, Its position is slightly higher and closer to the midline than the point farthest to the left.

Its height in human fetus is from $51.5 \%$ to $56.7 \%$ with hardly any change with gestational age. However, the distance from the midline varies from $17.1 \%$ to $22.1 \%$ becoming farther from the midline with advancing fetal age. Consequently, its position in Macacus cyclopsis may be said to be similar to that in a 10-monthold fetus.

The height of this point measured from the lower tip of the sternum is an average of $2.9 \mathrm{~cm}(36.5 \%)$, but in human fetus this value decreases with gestational age being $36.4 \%$ in the 5 th month but becoming $25.0 \%$ in the 10 th month. Therefore, the position in Macacus cyclopsis is closest to that in a 5-month-old fetus.

\section{Lung (Table 6)}

With respect to the lungs, the position of the upper and lower borders, the most medial point of the lower anterior edge, the most medial point of the lower posterior edge, the most lateral point of the lung, and the position of the interlobar fissure were investi- 
Table 6. Lungs

\begin{tabular}{|c|c|c|c|c|c|c|}
\hline \multirow{2}{*}{ Region } & \multicolumn{2}{|c|}{ Base point } & \multicolumn{2}{|c|}{$\begin{array}{l}\text { Measurements } \\
\text { based on } 12 \text { th } \\
\text { thoracic vertebra }\end{array}$} & \multicolumn{2}{|c|}{$\begin{array}{l}\text { Measurements } \\
\text { based on lower } \\
\text { tip of sternum }\end{array}$} \\
\hline & & & $\begin{array}{l}\text { Mean of } \\
\text { actual } \\
\text { measure- } \\
\text { ments }\end{array}$ & Ratio & $\begin{array}{c}\text { Mean of } \\
\text { actual } \\
\text { measure- } \\
\text { ments }\end{array}$ & Ratio \\
\hline $\begin{array}{l}\text { Height of upper border } \\
\text { of lung }\end{array}$ & $\begin{array}{l}\mathbf{L} \\
\mathbf{R}\end{array}$ & upper & $\begin{array}{l}10.2 \\
10.3\end{array}$ & $\begin{array}{l}92.7 \\
93.6\end{array}$ & $\begin{array}{l}6.9 \\
7.1\end{array}$ & $\begin{array}{l}87.1 \\
88.8\end{array}$ \\
\hline $\begin{array}{l}\text { Distance from midline } \\
\text { of upper border of lung }\end{array}$ & $\begin{array}{l}\mathrm{L} \\
\mathrm{R}\end{array}$ & $\begin{array}{l}\mathrm{L} \\
\mathrm{R}\end{array}$ & $\begin{array}{l}1.5 \\
1.4\end{array}$ & $\begin{array}{l}18.1 \\
16.9\end{array}$ & & \\
\hline $\begin{array}{l}\text { Height of lower border } \\
\text { of lung }\end{array}$ & $\begin{array}{l}\mathrm{L} \\
\mathrm{R}\end{array}$ & upper & $\begin{array}{c}-0.2 \\
0\end{array}$ & $\begin{array}{c}-1.8 \\
0\end{array}$ & $\begin{array}{l}-3.4 \\
-3.3\end{array}$ & $\begin{array}{l}-42.1 \\
-41.1\end{array}$ \\
\hline $\begin{array}{l}\text { Distance from midline } \\
\text { of lower border of lung }\end{array}$ & $\begin{array}{l}\mathrm{L} \\
\mathrm{R}\end{array}$ & $\begin{array}{l}\mathrm{L} \\
\mathrm{R}\end{array}$ & $\begin{array}{l}1.3 \\
1.1\end{array}$ & $\begin{array}{l}15.7 \\
13.3\end{array}$ & & \\
\hline $\begin{array}{l}\text { Height of most lateral } \\
\text { point of the lung }\end{array}$ & $\begin{array}{l}\mathrm{L} \\
\mathrm{R}\end{array}$ & upper & $\begin{array}{l}2.1 \\
2.2\end{array}$ & $\begin{array}{l}19.1 \\
20.0\end{array}$ & $\begin{array}{l}-1.2 \\
-1.1\end{array}$ & $\begin{array}{l}-14.5 \\
-14.3\end{array}$ \\
\hline $\begin{array}{l}\text { Distance from midline } \\
\text { of most lateral point of } \\
\text { lung }\end{array}$ & $\begin{array}{l}\mathrm{L} \\
\mathrm{R}\end{array}$ & $\begin{array}{l}\mathrm{L} \\
\mathrm{R}\end{array}$ & $\begin{array}{l}4.5 \\
4.4\end{array}$ & $\begin{array}{l}54.2 \\
53.0\end{array}$ & & \\
\hline $\begin{array}{l}\text { Height of most medial } \\
\text { point of lower anterior } \\
\text { edge of lung }\end{array}$ & $\begin{array}{l}\mathbf{L} \\
\mathbf{R}\end{array}$ & upper & $\begin{array}{l}3.8 \\
4.2\end{array}$ & $\begin{array}{l}34.5 \\
38.2\end{array}$ & $\begin{array}{l}0.6 \\
0.9\end{array}$ & $\begin{array}{r}7.3 \\
11.5\end{array}$ \\
\hline $\begin{array}{l}\text { Distance from midline of } \\
\text { most medial point of low. } \\
\text { er anterior edge of lung }\end{array}$ & $\begin{array}{l}\mathbf{L} \\
\mathbf{R}\end{array}$ & $\begin{array}{l}\mathrm{L} \\
\mathrm{R}\end{array}$ & $\begin{array}{l}1.8 \\
0.8\end{array}$ & $\begin{array}{r}21.6 \\
9.6\end{array}$ & & \\
\hline $\begin{array}{l}\text { Height of most medial } \\
\text { point of lower dorsal } \\
\text { edge of lung }\end{array}$ & $\begin{array}{l}\mathbf{L} \\
\mathbf{R}\end{array}$ & upper & $\begin{array}{l}1.3 \\
3.9\end{array}$ & $\begin{array}{l}11.8 \\
35.5\end{array}$ & $\begin{array}{r}-2.0 \\
0.6\end{array}$ & $\begin{array}{r}-25.5 \\
7.6\end{array}$ \\
\hline $\begin{array}{l}\text { Distance from midline of } \\
\text { most medial point of low- } \\
\text { er dorsal edge of lung }\end{array}$ & $\begin{array}{l}\mathrm{L} \\
\mathrm{R}\end{array}$ & $\begin{array}{l}\mathrm{L} \\
\mathrm{R}\end{array}$ & $\begin{array}{l}0.5 \\
1.2\end{array}$ & $\begin{array}{r}6.0 \\
14.5\end{array}$ & & \\
\hline \multirow{2}{*}{$\begin{array}{l}\text { Height of medial end of } \\
\text { interlobar fissure }\end{array}$} & \multirow[t]{2}{*}{ L } & \multirow{2}{*}{ upper } & $\begin{array}{l}6.3 \\
3.2\end{array}$ & $\begin{array}{l}57.3 \\
29.1\end{array}$ & $\begin{array}{r}2.9 \\
-0.1 \\
\end{array}$ & $\begin{array}{r}36.3 \\
-0.6\end{array}$ \\
\hline & & & $\begin{array}{l}6.8 \\
3.8\end{array}$ & $\begin{array}{l}61.8 \\
34.5\end{array}$ & $\begin{array}{l}3.5 \\
0.4\end{array}$ & $\begin{array}{r}43.5 \\
4.4\end{array}$ \\
\hline \multirow{2}{*}{$\begin{array}{l}\text { Distance from midline } \\
\text { of most medial end of } \\
\text { interlobar fissure }\end{array}$} & L & L & $\begin{array}{l}2.2 \\
2.8\end{array}$ & $\begin{array}{l}26.6 \\
33.7\end{array}$ & & \\
\hline & $\mathrm{R}$ & $\mathrm{R}$ & $\begin{array}{l}1.6 \\
2.3\end{array}$ & $\begin{array}{l}19.3 \\
27.7\end{array}$ & & \\
\hline \multirow{2}{*}{$\begin{array}{l}\text { Height of lateral end of } \\
\text { interlobar fissure }\end{array}$} & \multirow[b]{2}{*}{$\mathbf{R}$} & \multirow{2}{*}{ upper } & $\begin{array}{l}6.3 \\
4.4\end{array}$ & $\begin{array}{l}57.3 \\
40.0\end{array}$ & $\begin{array}{l}2.9 \\
1.0\end{array}$ & $\begin{array}{l}36.9 \\
12.6\end{array}$ \\
\hline & & & $\begin{array}{l}6.2 \\
4.6\end{array}$ & $\begin{array}{l}56.4 \\
41.8\end{array}$ & $\begin{array}{l}2.9 \\
1.3\end{array}$ & $\begin{array}{l}36.9 \\
15.8\end{array}$ \\
\hline \multirow{2}{*}{$\begin{array}{l}\text { Distance from midline } \\
\text { of most lateral end of } \\
\text { interlobar fissure }\end{array}$} & L & L & $\begin{array}{l}3.6 \\
4.1\end{array}$ & $\begin{array}{l}43.4 \\
49.4\end{array}$ & & . \\
\hline & $\mathbf{R}$ & $\mathbf{R}$ & $\begin{array}{l}3.5 \\
3.9\end{array}$ & $\begin{array}{l}42.2 \\
47.0\end{array}$ & & \\
\hline
\end{tabular}

L. 2..Left, R...Right. *...Direction from base point. .....Side. 
gated. Usually, in Macacus cyclopsis, the right lung is separated into four lobes while the left is separated into the three lobes. However, two interlobar fissures may be identified on the anterior surface of each lung delineating the upper, middle and lower lobes.

1) The height of the upper border of the lungs measured from the 12 th thoracic vertebra is at an average of $10.2 \mathrm{~cm}$. for the left lung and $10.3 \mathrm{~cm}$ for the right lung which in terms of converted values is $92.7 \%$ and $93.6 \%$ respectively. There is little difference between the two sides. The distance from the midline is an average of $1.5 \mathrm{~cm}$ for the left lung and $1.4 \mathrm{~cm}$ for the right lung with converted values of $18.1 \%$ and $16.9 \%$ respectively. The distance to each side also shows little difference by side.

When these values are compared with that for human fetus, both the distance from the base point and midline increase with gestational age in human fetus, but the ratio of the increase is small, the converted values for the height being in the range of $96.7 \%$ to $100.0 \%$ for the left lung and $97.0 \%$ to $100.0 \%$ for the right lung which are about $5 \%$ higher than that for Macacus cyclopsis. Also, the ratio of the distance to each side also does not change much being $15.2 \%$ to $17.1 \%$ for the left lung and $15.2 \%$ to $17.1 \%$ for the right lung which are not much different from that in Macacus cyclopsis.

Measured from the lower tip of the sternum, the average value is $6.9 \mathrm{~cm}$ for the left lung and $7.1 \mathrm{~cm}$ for the right lung with converted values of $87.1 \%$ and $88.8 \%$ respectively. In human fetus, the values are $100.0 \%$ on each side in the 5th month and corresponds almost completely to the level of the upper edge of the sternum, but in the terminal stage of fetal development it becomes slightly lower than the upper edge of the body of the sternum. When the two are compared, the height in Macacus cyclopsis is about $9 \%$ lower than in human fetus.

2) The anterior edge of the lower lobe in Macacus cyclopsis runs downward from the medial point to the lateral chest wall to form the most lateral point of the lung. It then continues downward along the posterior side of the thorax toward the midline. Therefore, the lower pole of the lung is extremely low.

The height of the lower border of the lung measured from the 12th thoracic vertebra is an average of $0.2 \mathrm{~cm}$ below the base point for the left lung while the right lung is almost level with the base 
point. The converted value for the left lung is $1.8 \%$ below the base point and slightly lower than the right lung. The distance from the midline is an average of $1.3 \mathrm{~cm}$ for the left lung and $1.1 \mathrm{~cm}$ for the right lung with converted values of $15.7 \%$ and $13.3 \%$ respectively which show that it is slightly further lateral in the left lung.

The average height of the lower border of the lung in human fetus increases with gestational age, but the converted values are $18.2 \%$ in the 5 th month and $19.2 \%$ in the left lung and $18.2 \%$ in the 5th month and $20.5 \%$ in the 10th month for the right lung which shows no definite change with gestational age. Also, the left lung is slightly lower than the right lung. The distance from the midline is $14.3 \%$ in the 5 th month and $16.9 \%$ in the 10 th month for the left lung while it is $17.1 \%$ in the 5 th month and $16.9 \%$ in the 10th month for the right lung with almost no difference by side.

Hence, comparison of Macacus cyclopsis and human fetus shows little difference in the distance from the midline, but the height is considerably lower in Macacus cyclopsis.

Measured from the lower tip of the sternum, the average value is $-3.4 \mathrm{~cm}$ for the left and $-3.3 \mathrm{~cm}$ for the right with converted values of $-42.1 \%$ and $-41.1 \%$ respectively.

In human fetus, the value is $22.7 \%$ for both sides in the 5 th month while in the 10 th month it is $36.4 \%$ on the left and $34.1 \%$ on the right with an increase in value with gestational age. Therefore, it may be said that the values are more similar to that for Macacus cyclopsis in the terminal period of fetal development, but even then it is higher than in Macacus cyclopsis.

3) The most lateral point of lung in Macacus cyclopsis corresponds to the point at which the lower ventral (anterior) edge passes along the lateral chest to become the lower dorsal (posterior) edge. The height of the most lateral point measured from the 12th thoracic vertebra is at an average of $2.1 \mathrm{~cm}(19.1 \%)$ for the left lung and $2.2 \mathrm{~cm}(20.0 \%)$ for the right lung. The distance from the midline is $4.5 \mathrm{~cm}(54.2 \%)$ for the left lung and $4.4 \mathrm{~cm}(53.0 \%)$ for the right lung. The height and distance from the midline is almost the same on each side.

This position in human fetus in the 5 th month is $30.3 \%$ for the left lung and $30.3 \%$ for the right lung and in the 10 th month it is $35.6 \%$ for the left lung and $36.9 \%$ for the right lung, but 
there is no apparent systematic change with gestational age. Also, the distance from the midline in the 5 th month of gestation is $45.7 \%$ for the left lung and $45.7 \%$ for the right lung while in the 10 th month it is $48.1 \%$ for the left and $49.4 \%$ on the right with increasing distance from the midline with age. Hence, the height of the most lateral point in Macacus cyclopsis is considerably lower than in human fetus and farther lateral from the midline.

When measured from the lower tip of the sternum, it is below the base point on both sides, the left lung being $-1.2 \mathrm{~cm}(14.5 \%)$ and the right lung $-1.1 \mathrm{~cm}(14.3 \%)$. In human fetus, it is 0 on both sides in the 5 th month while in the 10 th month it is $-9.1 \%$ on the left and $-6.8 \%$ for the right which shows that there is a gradual descent in human fetus with advance in gestational age. However, the position in Macacus cyclopsis is lower than that at any gestational age in human fetus.

4) The height of the most medial point of the lower anterior edge of the lung measured from the 12 thoracic vertebra is an average of $3.8 \mathrm{~cm}(34.5 \%)$ for the left lung and $4.2 \mathrm{~cm}(38.2 \%)$ for the right lung. The most medial point of the right lung is slightly higher.

In human fetus, both the actual value and converted value increase with gestational age being $27.3 \%$ on the left and $39.4 \%$ on the right in the 5 th month and $36.9 \%$ on the left and $43.8 \%$ on the right in the 10th month. The right lung also is found to be higher. When the values for Macacus cyclopsis are compared with human fetus, the ratio for the left lung is the same as that for a human fetus in the 10th month of development while the right lung is similar to that of a 5 month fetus. The most medial point of the right lung is higher than the left lung as in human fetus.

The distance of the most medial point of the lower anterior edge of the lung from the midline is an average of $1.8 \mathrm{~cm}(21.6 \%)$ on the left and $0.8 \mathrm{~cm}(9.7 \%)$ on the right.

In human fetus, this value is $31.4 \%$ for the left and $8.6 \%$ for the right lung in the 5 th month and $35.1 \%$ for the left and $19.5 \%$ for the right in the 10th month of gestation. Therefore, this point in both lungs is closer to the midline than in human fetus. However, both instances are similar in that the left lung is located more laterally than the right lung.

5) The most medial point of the lower dorsal edge of the lung measured from the 12th thoracic vertebra is an average of $1.3 \mathrm{~cm}$ 
$(11.8 \%)$ on the left and $3.9 \mathrm{~cm}(35.5 \%)$ on the right. The distance from the midline is $0.5 \mathrm{~cm}(6.0 \%)$ to the left of the midline for the left lung and $1.2 \mathrm{~cm}(14.5 \%)$ to the left of the midline for the right lung. The most medial point of the right lung is located to the left of the midline because of the peculiar shape of the right lung in Macacus cyclopsis in which in addition to the upper, middle and lower lobes, there is the presence of the lobus azygos which is adjacent to the upper medial side of the posterior part of the lower lung. The lobus azygos extends forward from behind the inferior vena cava toward the upper left to the left chest where it is located in front of the esophagus, below and behind the heart.

Measured from the lower tip of the sternum, the left lung is $25.5 \%$ below the base point but the location of the right lung is $7.6 \%$ above the base point. There is a difference by side.

6) Two interlobar fissures may be seen on the anterior surface of each lung. The height of their medial end measured from the 12 th thoracic vertebra is $6.3 \mathrm{~cm}$ and $3.2 \mathrm{~cm}$ with converted values of $57.3 \%$ and $29.1 \%$ respectively for the left $l$ ung and $6.8 \mathrm{~cm}$ and $3.8 \mathrm{~cm}$ with converted values of $61.8 \%$ and $34.5 \%$ respectively, for the right lung. Measured from the lower tip of the sternum, their average actual values are $2.9 \mathrm{~cm}$ and $-0.1 \mathrm{~cm}$ with converted values of $36.3 \%$ and $-0.6 \%$ respectively for the left lung and $3.5 \mathrm{~cm}$ and $0.4 \mathrm{~cm}$, or $43.5 \%$ and $4.4 \%$ respectively for the right lung.

The distance from the midline is an average of $2.2 \mathrm{~cm}$ and 2.8 $\mathrm{cm}(26.6 \%$ and $33.7 \%)$ for the left lung and $1.6 \mathrm{~cm}$ and $2.3 \mathrm{~cm}(19.3 \%$ and $27.7 \%$ ) for the right lung.

The lateral end of the interlobar fissures, measured from the 12 th thoracic vertebra, is an average of $6.3 \mathrm{~cm}$ and $4.4 \mathrm{~cm}$, with converted values of $57.3 \%$ and $40.0 \%$ respectively for the left lung and $6.2 \mathrm{~cm}$ and $4.6 \mathrm{~cm}$, or $56.4 \%$ and $41.8 \%$ respectively for the right lung. Measured from the lower tip of the sternum, the average actual value for the left lung is $2.9 \mathrm{~cm}$ and $1.0 \mathrm{~cm}$ with converted values of $36.9 \%$ and $12.6 \%$ respectively and for the right lung it is $2.9 \mathrm{~cm}$ and $1.3 \mathrm{~cm}$, or $36.3 \%$ and $15.8 \%$ respectively.

The distance from the midline is an average of $3.6 \mathrm{~cm}$ and 4.1 $\mathrm{cm}$ with converted values of $43.4 \%$ and $49.4 \%$ for the left lung and $3.5 \mathrm{~cm}$ and $3.9 \mathrm{~cm}$ with converted values of $42.2 \%$ and $47.0 \%$ for the right lung. Consequently, of the interlobar fissures on the anterior surface, the upper fissures on each side are generally horizontal 
while the lower fissures rise slightly toward the lateral side.

\section{Esophagus and blood vessels (Table 7, 8 and 9)}

The location at which the esophagus, the thoracic aorta and inferior vena cava penetrate the diaphragm were measured from the level of the 12 th thoracic vertebra.

1) The level at which the esophagus penetrates the diaphragm as measured from the 12th thoracic vertebra is an average of $2.5 \mathrm{~cm}$ $(22.7 \%)$. The distance from the midline at the left edge is $0.7 \mathrm{~cm}$ (8.4\%) to the left of the midline and the right edge likewise is to the left of the midline by $0.2 \mathrm{~cm}$ (or $2.4 \%$ ) which indicates that the penetration is very close to the midline just left of the midline.

2) The level at which the thoracic aorta penetrates the diaphragm is considerably lower than that for the esophagus and lower than the base point. It is at an average of $-2.6 \mathrm{~cm}(-23.6 \%)$ and the left edge is $0.4 \mathrm{~cm}(4.8 \%)$ to the left of the midline while the right edge is $0.1 \mathrm{~cm}(1.2 \%)$ right of the midline. Therefore, as a whole, it penetrates the diaphragm slightly more to the left of the midline.

3) The level at which the inferior vena cava penetrates the diaphragm is higher than that for the esophagus or thoracic aorta. It is at a level of $3.4 \mathrm{~cm}(30.9 \%)$ and the left edge is $0.9 \mathrm{~cm}(10.8 \%)$ to the right of the midline while the right edge is $1.4 \mathrm{~cm}(16.8 \%)$ to the right of the midline.

Therefore, the relation of these three locations of penetration is the thoracic aorta in the center with the esophagus on the left and the inferior vena cava on the right.

Next, the relation between the esophagus and the bronchi, the relation between the major blood vessels and the heart and lungs, and the position of the bifurcation and junction of principal blood vessels were investigated and illustrated.

4) The level at which the inferior vena cava enters the heart is $5.2 \mathrm{~cm}(47.3 \%)$ above the 12 th thoracic vertebra and $1.0 \mathrm{~cm}(12.0 \%)$ to the right of the midline which is approximately $6 \%$ higher and slightly closer to the midline than the position of the penetration of the inferior vena cava through the diaphragm.

5) The esophagus and left bronchus cross each other. The location 


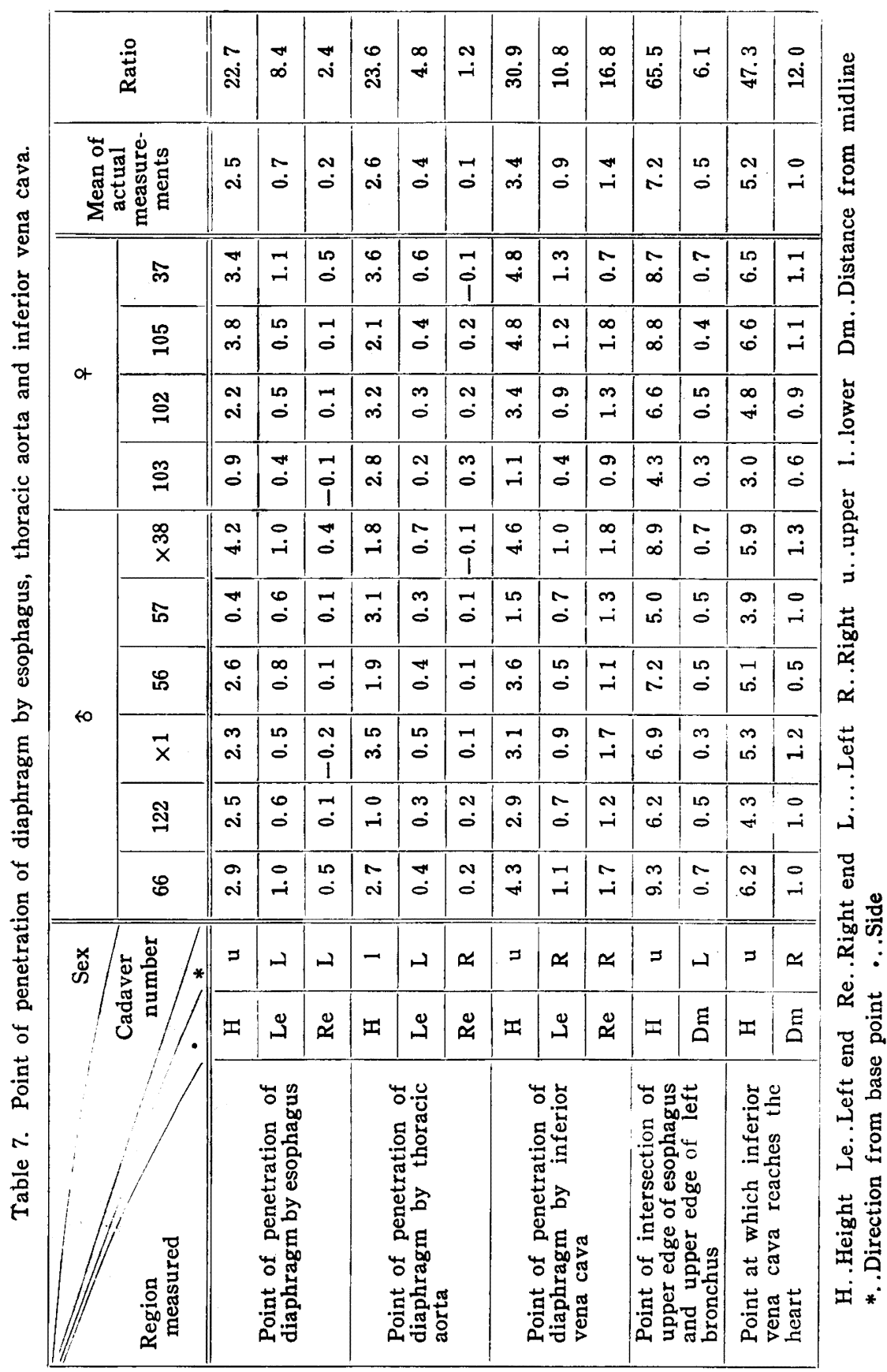


at which the left edge of the esophagus and the upper edge of the left bronchus cross is $7.2 \mathrm{~cm}(65.5 \%)$ above the 12 th thoracic vertebra and $0.5 \mathrm{~cm}(6.1 \%)$ to the left of the midline.

6) The position of the entry of the pulmonary artery and pulmonary vein into the hilum is as follows: The artery enters the left hilum at the level of $6.9 \mathrm{~cm}(62.7 \%)$ and is $1.2 \mathrm{~cm}(14.5 \%)$ from the midline. In the right hilum the arteries enter a height of $7.5 \mathrm{~cm}$ and $6.7 \mathrm{~cm}$, or $68.2 \%$ and $60.9 \%$ respectively while the distance from the midline is $1.3 \mathrm{~cm}(15.7 \%)$ for both.

The veins enter the hilum at a level of $6.9 \mathrm{~cm}$ and $5.4 \mathrm{~cm}(62.7 \%$ and $49.1 \%$ ) with a distance of $1.4 \mathrm{~cm}$ and $0.5 \mathrm{~cm}(16.9 \%$ and $6.0 \%)$ from the midline in the left lung while in the right lung it is at a level of $6.7 \mathrm{~cm}$ and $5.5 \mathrm{~cm}(60.9 \%$ and $50.0 \%)$ with a distance of $1.5 \mathrm{~cm}$ and $0.5 \mathrm{~cm}(18.1 \%$ and $6.0 \%)$ from the midline. There is not much difference by side.

7) The origin of the aorta is at a level of $7.6 \mathrm{~cm}(69.1 \%)$. The distance from the midline is $0.3 \mathrm{~cm}(3.6 \%)$ to the left of the midline.

The apex of the aortic arch is at a height of $8.6 \mathrm{~cm}(78.2 \%)$ and is approximately $9 \%$ higher than the origin of the aorta. The distance from the midline is $0.6 \mathrm{~cm}(7.2 \%)$ to the left of the midline which is about $3 \%$ further to the left than the origin of the aorta.

The height at which the brachiocephalic artery arises from the aortic arch is at $8.6 \mathrm{~cm}(78.2 \%)$ which is generally the same as the height of the apex of the aortic arch, but the distance from the midline is $0.5 \mathrm{~cm}(6.0 \%)$ to the left which is slightly closer to the midline.

The height at which the left subclavian artery arises from the aortic artery is $8.4 \mathrm{~cm}(76.4 \%)$ and the distance from the midline is $0.8 \mathrm{~cm}(9.6 \%)$ to the left which are $2 \%$ lower and $2 \%$ lateral to the apex of the aortic arch.

8) The height at which the brachiocephalic artery separates into the right common carotid and the right subclavian arteries is 10.3 $\mathrm{cm}(93.6 \%)$ which is approximately $15 \%$ higher than the point of separation of the brachiocephalic artery from the aortic arch. The distance from the midline is $0.5 \mathrm{~cm}(6.0 \%)$ to the right of the midline which is about $12 \%$ to the right of the point of separation of the brachiocephalic artery.

The height at which the left common carotic artery arises from 
Mikio Naruse

\begin{tabular}{|c|c|c|c|c|c|c|c|c|c|c|c|c|}
\hline \multicolumn{2}{|c|}{ 胥 } & कृ. & $\stackrel{0}{\dot{m}}$ & $\stackrel{\sim}{\infty}$ & $\stackrel{\sim}{\sim}$ & $\overrightarrow{8}$ & 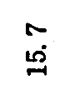 & $\begin{array}{l}\sim \\
\infty \\
\infty\end{array}$ & : & $\begin{array}{l}0 \\
\ddot{8}\end{array}$ & $\ddot{0}$ & $\stackrel{L}{\infty}$ \\
\hline \multicolumn{2}{|c|}{ 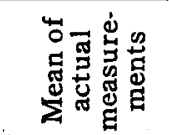 } & $\stackrel{\circ}{\circ}$ & $\stackrel{m}{0}$ & $\begin{array}{l}0 \\
\infty\end{array}$ & $\begin{array}{l}0 \\
0\end{array}$ & $\stackrel{\circ}{\circ}$ & $\stackrel{m}{-}$ & $\begin{array}{l}0 \\
\infty\end{array}$ & : & $\begin{array}{l}m \\
\stackrel{0}{-}\end{array}$ & $\ddot{0}$ & $\stackrel{m}{\sigma}$ \\
\hline \multirow{4}{*}{ of } & $\tilde{\text { ஸे }}$ & $\stackrel{10}{\circ}$ & $\stackrel{N}{0}$ & $\stackrel{m}{\circ}$ & $\ddot{0}$ & $\ddot{0}$ & $\stackrel{m}{-1}$ & $\stackrel{m}{\circ}$ & $\stackrel{10}{0}$ & $\stackrel{9}{\Rightarrow}$ & $\tilde{0}$ & $\stackrel{\circ}{\dot{I}}$ \\
\hline & 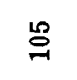 & $\stackrel{m}{\sigma}$ & $\stackrel{m}{0}$ & $\begin{array}{l}\infty \\
\sigma^{\circ}\end{array}$ & $\tilde{0}$ & $\begin{array}{l}\infty \\
\infty \\
\infty\end{array}$ & $\stackrel{0}{-1}$ & $\begin{array}{l}\infty \\
\sigma\end{array}$ & $\tilde{0}$ & $\begin{array}{l}\text { N } \\
\text { తิ }\end{array}$ & $\stackrel{N}{0}$ & $\stackrel{\sim}{\exists}$ \\
\hline & 今్ & $\stackrel{m}{\sim}$ & $\stackrel{\pi}{0}$ & $\underset{\infty}{\sim}$ & $\tilde{0}$ & $\begin{array}{l}0 \\
0 \\
0\end{array}$ & $\stackrel{\sim}{\sim}$ & $\underset{\infty}{\sim}$ & $\tilde{0}$ & $\hat{\sigma}$ & $\ddot{\circ}$ & $\underset{\infty}{\infty}$ \\
\hline & ஜ̊ㄱㅁ & $\stackrel{L}{*}$ & : & $\begin{array}{l}\text { * } \\
\text { is }\end{array}$ & $\ddot{0}$ & $\overrightarrow{\text { in }}$ & $\exists$ & $\begin{array}{l}\text { No } \\
\text { is }\end{array}$ & $\begin{array}{l}0 \\
0\end{array}$ & $\stackrel{0}{0}$ & $\stackrel{10}{0}$ & is \\
\hline \multirow{6}{*}{ to } & $\stackrel{\infty}{\stackrel{\rho}{x}}$ & $\tilde{\sigma}$ & $\stackrel{m}{0}$ & : & 10 & $\stackrel{\circ}{\circ}$ & $\stackrel{0}{-}$ & $\stackrel{\pi}{\dot{9}}$ & $\stackrel{10}{0}$ & $\underset{\sim}{\sim}$ & $\tilde{0}$ & $\stackrel{m}{=}$ \\
\hline & 战 & in & 0 & $\begin{array}{l}\infty \\
\dot{0}^{\circ}\end{array}$ & $\stackrel{m}{0}$ & $\stackrel{\sim}{\oplus}$ & $\stackrel{0}{-i}$ & $\begin{array}{l}\infty \\
0 \\
0\end{array}$ & $\stackrel{m}{0}$ & $\underset{\infty}{N}$ & $\stackrel{m}{0}$ & $\stackrel{\circ}{\stackrel{\circ}{*}}$ \\
\hline & 노 & $\stackrel{\square}{\circ}$ & $\grave{0}$ & $\vec{\infty}$ & $\tilde{0}$ & $\stackrel{\sim}{\sim}$ & $\stackrel{m}{-}$ & $\stackrel{9}{i}$ & $\stackrel{10}{0}$ & $\overrightarrow{0}$ & $\begin{array}{l}0 \\
0\end{array}$ & $\begin{array}{l}\sim \\
0\end{array}$ \\
\hline & $\vec{x}$ & $\stackrel{\infty}{\sim}$ & $\begin{array}{l}m \\
i \\
i\end{array}$ & $\stackrel{\sim}{\infty}$ & $\ddot{0}$ & $\stackrel{m}{\sim}$ & $\stackrel{\sim}{\sim}$ & $\stackrel{\sim}{\infty}$ & 10 & $\begin{array}{l}\infty \\
\stackrel{0}{0}\end{array}$ & $\stackrel{0}{0}$ & $\begin{array}{l}N \\
0\end{array}$ \\
\hline & సิ & $\stackrel{\sim}{0}$ & $\ddot{m}$ & $i$ & $\stackrel{m}{0}$ & $\stackrel{\sim}{0}$ & $\stackrel{-}{-}$ & $\dddot{\imath}$ & $\stackrel{m}{0}$ & $\stackrel{\sim}{\infty}$ & $\overrightarrow{0}$ & $\stackrel{?}{\sim}$ \\
\hline & 8 & $\ddot{m}$ & $\tilde{0}$ & $\begin{array}{l}0 \\
\text { ¿ }\end{array}$ & $\tilde{0}$ & $\tilde{\sigma}$ & $\stackrel{m}{-1}$ & $\begin{array}{l}0 \\
\dot{9}\end{array}$ & $\tilde{0}$ & $\begin{array}{l}\stackrel{0}{9} \\
\dot{m}\end{array}$ & 年 & $\stackrel{g}{\Rightarrow}$ \\
\hline \multirow[t]{2}{*}{ ڤ્㐅 } & & 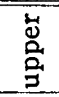 & $\stackrel{\rightleftarrows}{ٍ}$ & $\begin{array}{l}\breve{心} \\
\text { 号 }\end{array}$ & 岂 & 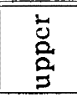 & $\underset{\Xi}{ \pm}$ & $\begin{array}{l}\text { 岕 } \\
\stackrel{a}{\rightrightarrows g}\end{array}$ & 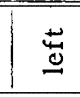 & $\begin{array}{l}\overrightarrow{\mathrm{d}} \\
\stackrel{2}{2} \\
3\end{array}$ & $\begin{array}{l}\overrightarrow{\vec{H}} \\
\vec{H}\end{array}$ & $\begin{array}{l}\text { 岕 } \\
\text { 音 }\end{array}$ \\
\hline & 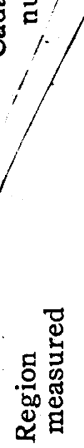 & 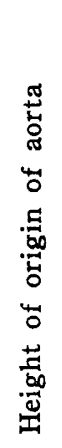 & 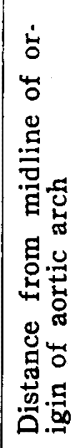 & 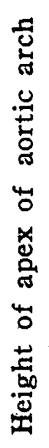 & 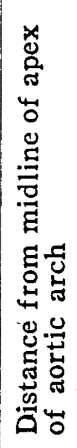 & 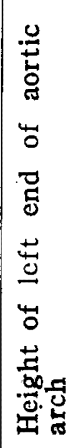 & 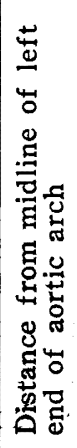 & 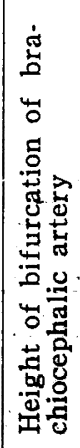 & 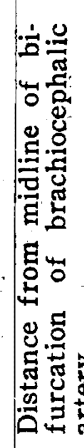 & 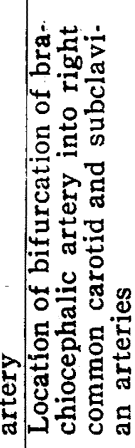 & 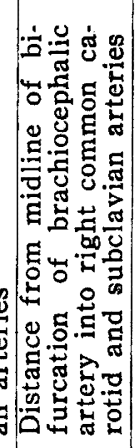 & 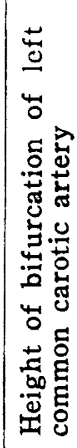 \\
\hline
\end{tabular}


On the Position of Thoracic Organs in Macacus cyclopsis

\begin{tabular}{|c|c|c|c|c|c|c|c|c|c|c|c|c|c|c|}
\hline$\stackrel{\infty}{+i}$ & $\ddot{0}$ & $\begin{array}{l}\dot{0} \\
\dot{\sigma}\end{array}$ & $\begin{array}{l}N \\
\infty \\
\infty\end{array}$ & $\begin{array}{l}N \\
\stackrel{\infty}{\infty}\end{array}$ & ஸ் & เి & $\stackrel{m}{\stackrel{\infty}{\infty}}$ & $\begin{array}{l}\dot{p} \\
\dot{m}\end{array}$ & $\begin{array}{l}\dot{8} \\
\stackrel{8}{ }\end{array}$ & $\begin{array}{l}\text { 엄 } \\
\text { తn}\end{array}$ & $\overrightarrow{8}$ & $\underset{\infty}{\infty}$ & $\tilde{\mathrm{N}}$ & $\begin{array}{l}\infty \\
\stackrel{0}{0}\end{array}$ \\
\hline$\stackrel{\square}{\circ}$ & $\underset{\infty}{+}$ & $\begin{array}{l}\infty \\
0\end{array}$ & $\begin{array}{l}\infty \\
\stackrel{0}{-1}\end{array}$ & $\begin{array}{l}\infty \\
\stackrel{0}{0}\end{array}$ & $\stackrel{m}{-}$ & $\stackrel{m}{-}$ & $\begin{array}{l}0 \\
\dot{\sigma}\end{array}$ & $\stackrel{m}{0}$ & $\tilde{\sim}$ & $\stackrel{0}{i}$ & $\stackrel{\leftrightarrow}{\sim}$ & $\tilde{0}$ & $\begin{array}{l}0 \\
\infty\end{array}$ & $\stackrel{0}{0}$ \\
\hline$\stackrel{\sim}{\circ}$ & $\ddot{\circ}$ & $\tilde{0}$ & $\stackrel{m}{\stackrel{\sim}{\sim}}$ & $\begin{array}{l}\stackrel{0}{ } \\
\stackrel{\sim}{ }\end{array}$ & $\stackrel{\sigma}{0}$ & $\stackrel{N}{\sim}$ & $\stackrel{\vec{\prime}}{\vec{\prime}}$ & $\begin{array}{l}10 \\
0\end{array}$ & $\begin{array}{l}0 \\
\dot{\sigma}\end{array}$ & $\stackrel{\circ}{-}$ & $\stackrel{+}{\sigma}$ & $\tilde{0}$ & $\dot{\theta}$ & $\stackrel{\circ}{i}$ \\
\hline$\stackrel{10}{0}$ & $\begin{array}{l}0 \\
\dot{0}\end{array}$ & $\begin{array}{l}0 \\
\dot{0}\end{array}$ & $\begin{array}{l}\dot{m} \\
\text { ஸे }\end{array}$ & $\begin{array}{l}0 \\
\stackrel{\sim}{\sim}\end{array}$ & $\stackrel{0}{i}$ & $\stackrel{m}{\rightarrow}$ & $\begin{array}{l}\text { N } \\
\dot{z}\end{array}$ & $\stackrel{0}{0}$ & $\vec{\sigma}$ & $\begin{array}{l}0 \\
-i\end{array}$ & $\sigma^{*}$ & $\tilde{0}$ & $\begin{array}{l}10 \\
0^{\circ}\end{array}$ & $\begin{array}{l}\infty \\
0\end{array}$ \\
\hline $\begin{array}{l}0 \\
\dot{0}\end{array}$ & $\stackrel{\rho}{\stackrel{2}{2}}$ & $\exists$ & $\begin{array}{l}\llcorner \\
\stackrel{\leftrightarrow}{\mathcal{G}}\end{array}$ & $\begin{array}{l}0 \\
\stackrel{\mathfrak{I}}{\sim}\end{array}$ & $\stackrel{m}{-}$ & $\stackrel{\circ}{i}$ & $\stackrel{\sim}{\infty}$ & $\stackrel{\sim}{\sim}$ & $\stackrel{+}{N}$ & $\stackrel{0}{i}$ & $\stackrel{\infty}{\sim}$ & $\begin{array}{l}0 \\
0\end{array}$ & $\stackrel{0}{\sim}$ & $\tilde{0}$ \\
\hline$\stackrel{10}{0}$ & $\overrightarrow{\text { is }}$ & $\stackrel{-}{-}$ & $\stackrel{m}{\circ}$ & $\overrightarrow{0}$ & $\rightleftarrows$ & $\stackrel{\theta}{\dot{0}}$ & $\stackrel{0}{\circ}$ & 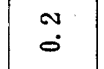 & $\stackrel{\infty}{+}$ & $\stackrel{0}{0}$ & $\stackrel{\oplus}{+}$ & $\ddot{\circ}$ & $\begin{array}{l}0 \\
10\end{array}$ & $\stackrel{0}{0}$ \\
\hline$\stackrel{+}{\circ}$ & $\ddot{\circ}$ & $\tilde{0}$ & $\begin{array}{l}0 \\
0\end{array}$ & $\stackrel{\circ}{\stackrel{2}{2}}$ & $\stackrel{10}{-i}$ & $\stackrel{10}{-1}$ & $\begin{array}{l}0 \\
=\end{array}$ & $\stackrel{v}{0}$ & $\begin{array}{l}\infty \\
\infty\end{array}$ & $\stackrel{\sim}{\stackrel{N}{\sim}}$ & $\begin{array}{l}0 \\
\dot{\sigma}\end{array}$ & $\tilde{\sigma}$ & $\stackrel{\sim}{\sigma}$ & i \\
\hline$\stackrel{N}{0}$ & $\begin{array}{l}\infty \\
\mathscr{0}^{0}\end{array}$ & مُ & $\overrightarrow{\dot{m}}$ & $\begin{array}{l}\stackrel{0}{\oplus} \\
\dot{\sim}\end{array}$ & $\stackrel{m}{\rightarrow}$ & $\stackrel{\sim}{\sim}$ & $\stackrel{\circ}{\sim}$ & $\stackrel{m}{0}$ & is & $\overrightarrow{-}$ & in & $\begin{array}{l}0 \\
0\end{array}$ & 0 & $\stackrel{\sim}{\sim}$ \\
\hline$\stackrel{m}{\circ}$ & $\vec{\infty}$ & $\grave{0}$ & $\begin{array}{l}\infty \\
\infty\end{array}$ & $\stackrel{\circ}{\circ}$ & 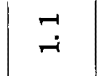 & $\stackrel{m}{\stackrel{m}{-}}$ & $\stackrel{+}{\sigma}$ & $\stackrel{m}{0}$ & $\stackrel{m}{\sim}$ & $\begin{array}{l}10 \\
0 \\
0\end{array}$ & 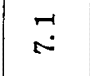 & $\grave{0}$ & 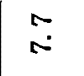 & $\begin{array}{l}10 \\
0\end{array}$ \\
\hline$\stackrel{m}{0}$ & $\stackrel{m}{\infty}$ & $\tilde{0}$ & $\begin{array}{l}\infty \\
\stackrel{\oplus}{\oplus}\end{array}$ & $\begin{array}{l}10 \\
\stackrel{0}{9}\end{array}$ & $\stackrel{20}{-10}$ & $\begin{array}{l}g \\
-i\end{array}$ & $\tilde{\sigma}$ & $\stackrel{\square}{0}$ & $\stackrel{9}{\stackrel{2}{\circ}}$ & $\stackrel{\sim}{\sim}$ & $\stackrel{\Delta}{\stackrel{2}{*}}$ & $\overrightarrow{0}$ & $\stackrel{\infty}{\infty}$ & $\stackrel{ت}{-}$ \\
\hline$\stackrel{N}{0}$ & $\vec{N}$ & $\begin{array}{l}\infty \\
0\end{array}$ & $\stackrel{\circ}{\circ}$ & $\begin{array}{l}\sim \\
\dot{\sigma}\end{array}$ & $\stackrel{\sim}{\sim}$ & 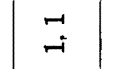 & $\begin{array}{l}\infty \\
\infty\end{array}$ & $\stackrel{\square}{0}$ & $\begin{array}{l}10 \\
0\end{array}$ & $\tilde{0}$ & $\stackrel{0}{0}$ & $\begin{array}{l}10 \\
0\end{array}$ & $\begin{array}{l}\infty \\
0^{\circ}\end{array}$ & $\begin{array}{l}0 \\
\dot{0}\end{array}$ \\
\hline$\stackrel{0}{\circ}$ & $\stackrel{\check{g}}{\circ}$ & $\stackrel{8}{\circ}$ & $\begin{array}{l}0 \\
\ddot{\rightarrow}\end{array}$ & $\begin{array}{l}m \\
m\end{array}$ & $\stackrel{\square}{-}$ & $\vec{H}$ & $\overrightarrow{\mathrm{S}}$ & $\stackrel{\sim}{0}$ & $\begin{array}{l}10 \\
0\end{array}$ & $\stackrel{\circ}{-}$ & $\stackrel{m}{\infty}$ & ت. & $\begin{array}{l}0 \\
\dot{\sigma}\end{array}$ & $\stackrel{0}{\circ}$ \\
\hline 苞 & $\begin{array}{l}\text { 岁 } \\
\text { 总 }\end{array}$ & $\underset{\Xi}{ \pm}$ & $\begin{array}{l}\ddot{\tilde{J}} \\
\stackrel{0}{\Xi}\end{array}$ & 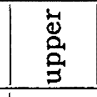 & 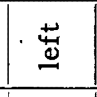 & 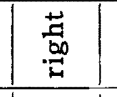 & 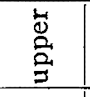 & $\begin{array}{l}\overrightarrow{7} \\
.00 \\
\end{array}$ & 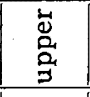 & $\begin{array}{l}\vec{n} \\
.00 \\
\end{array}$ & $\begin{array}{l}\text { 岕 } \\
\stackrel{0}{g} \\
\end{array}$ & $\underset{ٍ}{\stackrel{\rightleftarrows}{\Xi}}$ & $\begin{array}{l}\frac{\breve{d}}{0} \\
\frac{0}{z}\end{array}$ & 䔍 \\
\hline 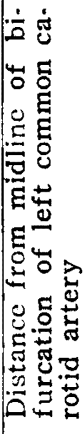 & 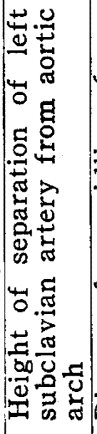 & 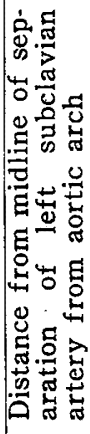 & 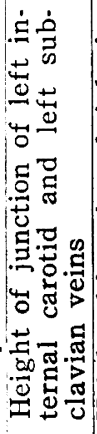 & 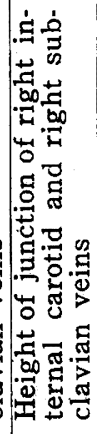 & 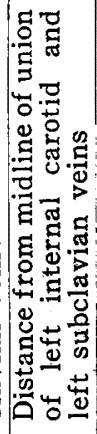 & 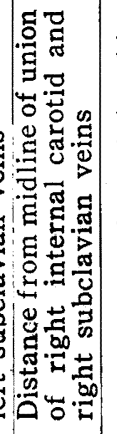 & 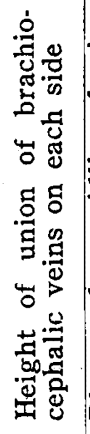 & 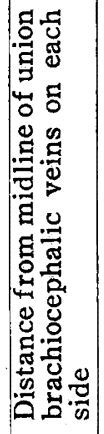 & 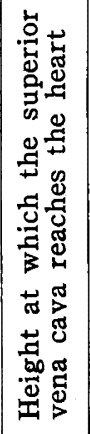 & 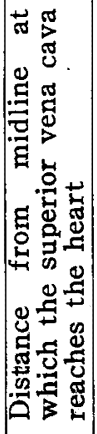 & 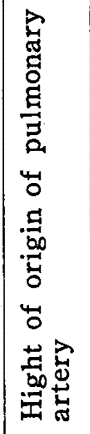 & 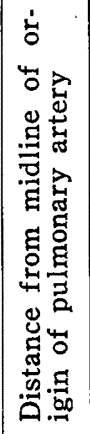 & 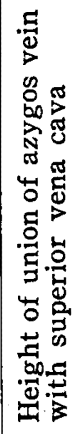 & 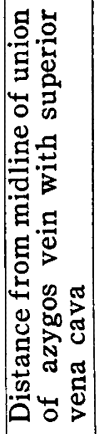 \\
\hline
\end{tabular}




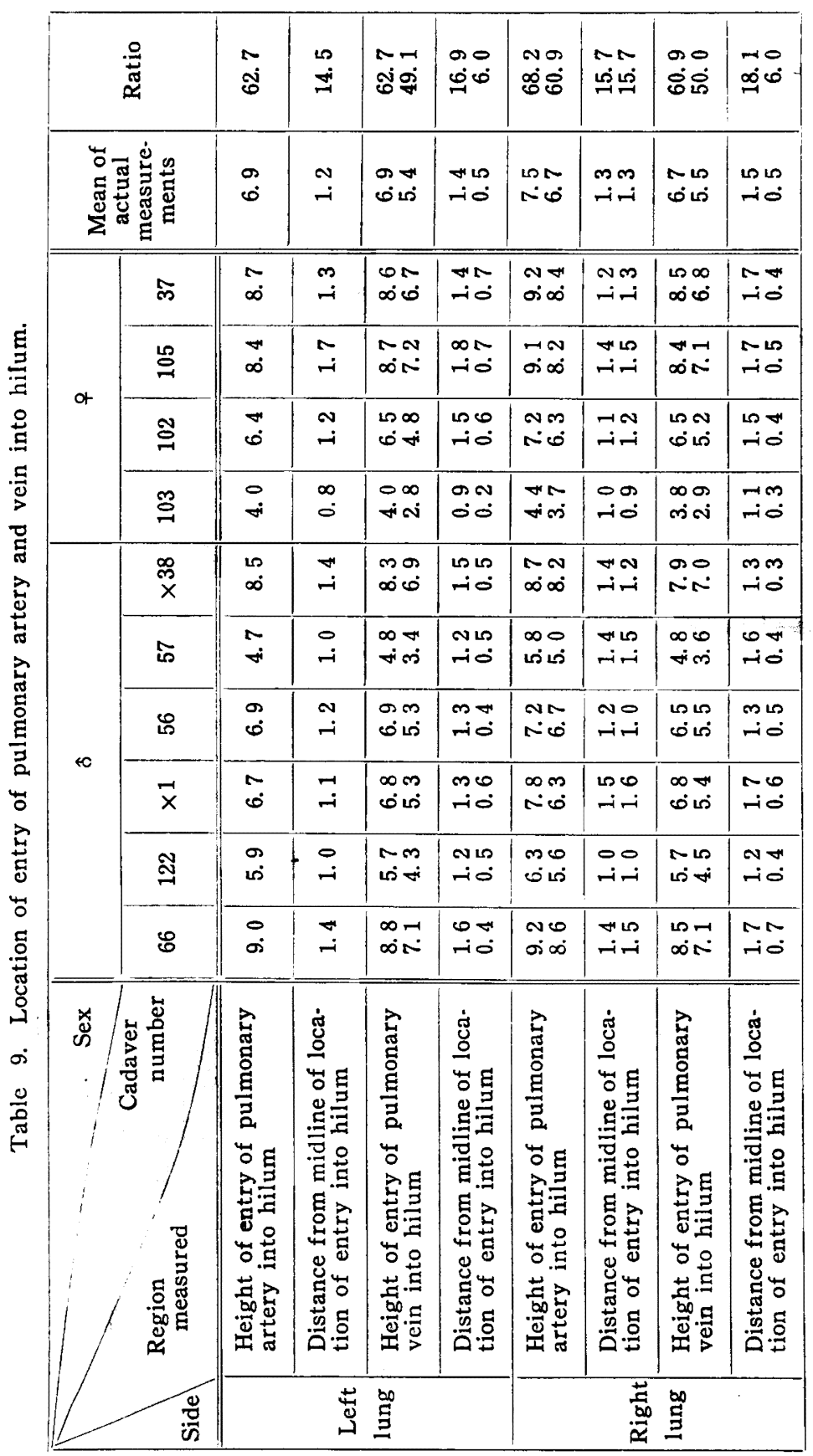


the brachiocephalic artery is $9.3 \mathrm{~cm}(84.5 \%)$ which is about $6 \%$ higher than the point of separation of the brachiocephalic artery. The distance from the midline is $0.4 \mathrm{~cm}(4.8 \%)$ to the left of the midline which is $1 \%$ closer to the midline than the point of bifurcation of the brachiocephalic artery.

9) The union of the internal carotid and subclavian veins occurs on the average at the same level on each side being at a height of $10.8 \mathrm{~cm}(98.2 \%)$ while the distance from the midline is $1.3 \mathrm{~cm}(15.7 \%)$ on each side of the midline respectively. This is $4.6 \%$ higher and $9.7 \%$ lateral to the point of bifurcation of the right subclavian artery from the brachiocephalic artery.

10) The level of the union of the brachiocephalic veins is $9.6 \mathrm{~cm}$ '87.3\%) and the distance from the midline is $0.3 \mathrm{~cm}(3.6 \%)$ to the right. This is approximately $3 \%$ higher than the point of the bifurcation of the left common carotic artery from the brachiocephalic artery and these points are at about equal distances on opposite sides of the midline.

11) The point at which the superior vena cava reaches the heart is at a height of $7.7 \mathrm{~cm}(70 \%)$ which is about $7 \%$ lower than the upper border of the heart and is $1.0 \mathrm{~cm}(12 . \%)$ to the right of the midline. The location at which the azygos vein joins the superior vena cava is at the height of $8.0 \mathrm{~cm}(72.7 \%)$ which is approximately $3 \%$ higher than the location at which the superior vena cava reaches the heart. The distance from the midline is $0.9 \mathrm{~cm}(10.8 \%)$ to the right.

12) The location of the origin of the pulmonary artery is at a height of $7.6 \mathrm{~cm}(69.1 \%)$ which is almost the same height as the origin of the aorta. The distance from the midline is $0.7 \mathrm{~cm}(8.4 \%)$ to the left which is about $4 \%$ farther lateral than the origin of the aorta.

\section{Summary}

A study was done on 20 bodies of adult Macacus cyclopsis in which the position of the various thoracic organs were measured and their relation to each other was reviewed.

In these measurements, the middle of the upper edge of the 12 th thoracic vertebra and the lower tip of the sternum were used as 
the base points for the calculation of the height while the distance to each side was based upon the midline. In addition, the findings were compared with that for human fetus obtained by myself using similar methods of measurements. In such comparisons, the ratio values were used.

The items of investigation for Macacus cyclopsis were as follows:

1. Trachea

1) Tip of angle of bifurcation of trachea

2) Point of entry of each bronchus into hilum

2. Heart

1) Upper border

2) Lower border

3) Most lateral point on each side

3. Lungs

1) Upper border

2) Lower border

3) Most medial point of the lower anterior edge

4) Most lateral point

5) Most medial point of lower dorsal edge

6) Interlober fissure

4. Esophagus and blood vessels

1) The relation of the esophagus, thoracic aorta and inferior vena cava to the diaphragm

2) The relation of the superior and inferior vena cava to the heart

3) Esophagus and bronchi

4) Pulmonary artery and pulmonary vein at the hilum

5) Origin, apex, and location of bifurcation of brachiocephalic and left subclavian arteries from aorta

6) Location of bifurcation of left common carotid, right common carotid and right subclavian arteries from brachiocephalic artery

7) Point of union of internal carotid and subclavian veins

8) Point of union of brachiocephalic veins

9) Location of origin of pulmonary artery 


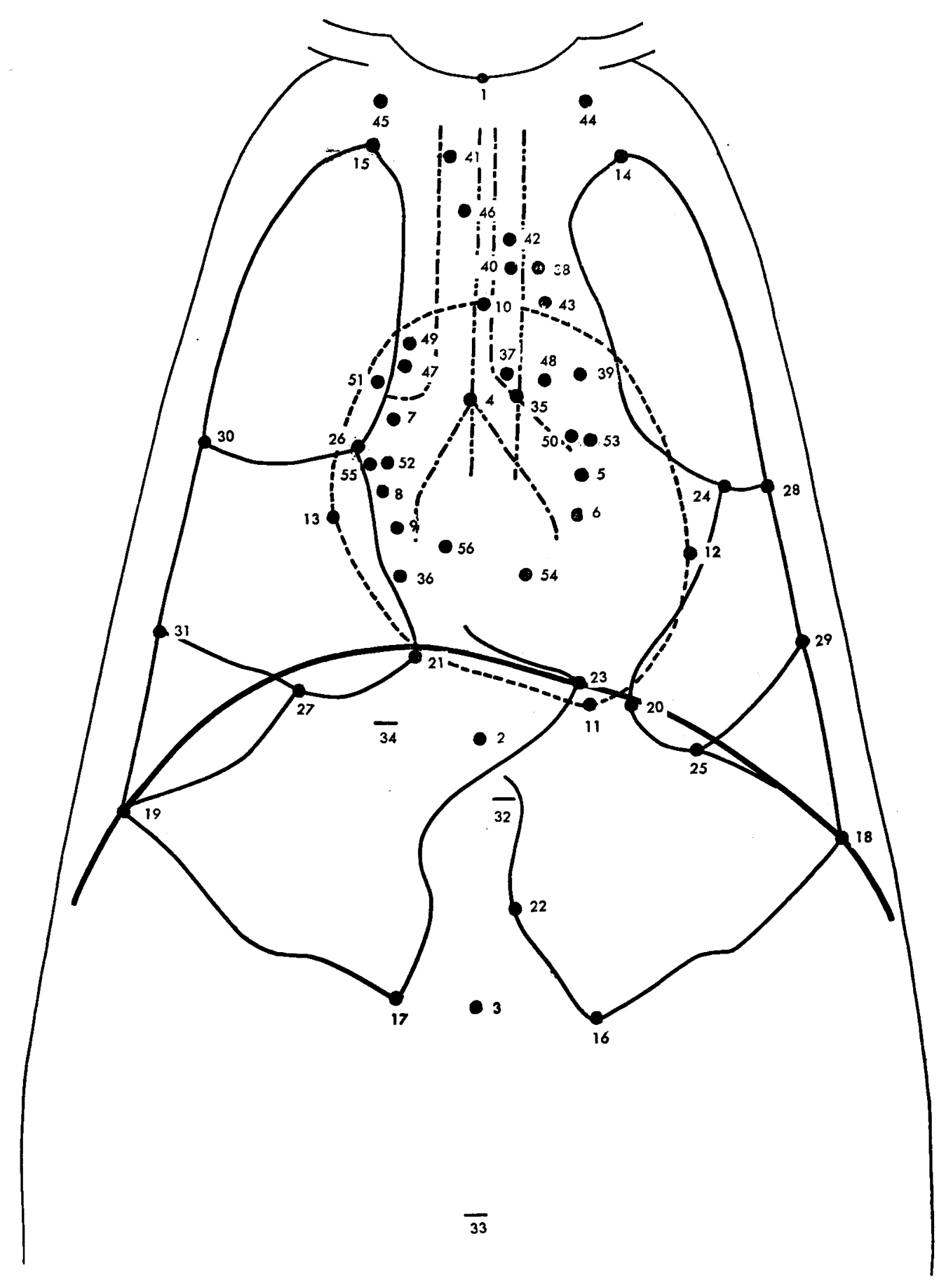


Fig. 1. Points for measurements of thoracic organs.

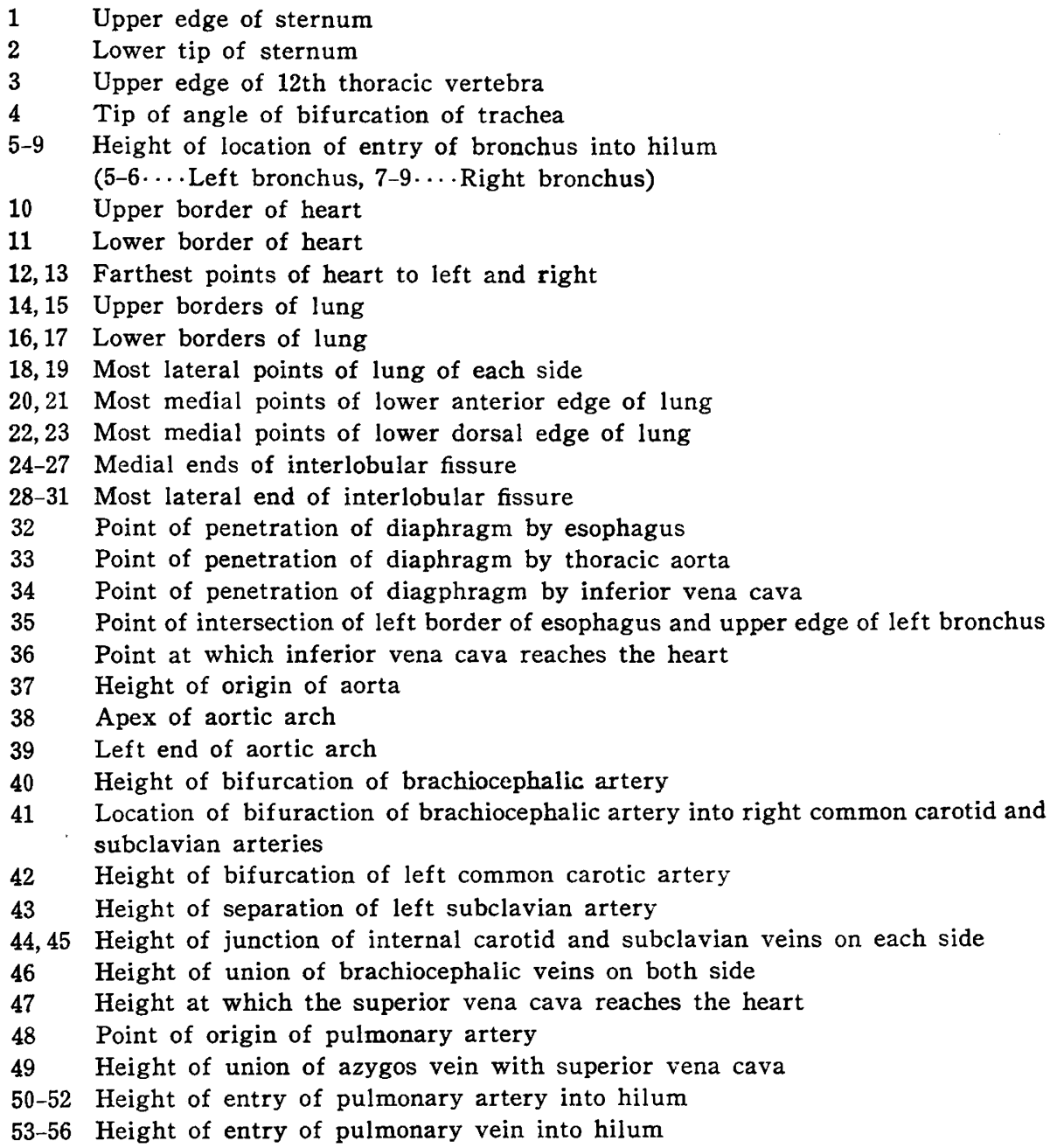

12,13 Farthest points of heart to left and right

18, 19 Most lateral points of lung of each side

20,21 Most medial points of lower anterior edge of lung

22, 23 Most medial points of lower dorsal edge of lung

24-27 Medial ends of interlobular fissure

28-31 Most lateral end of interlobular fissure

32 Point of penetration of diaphragm by esophagus

33 Point of penetration of diaphragm by thoracic aorta

34 Point of penetration of diagphragm by inferior vena cava

35 Point of intersection of left border of esophagus and upper edge of left bronchus

36 Point at which inferior vena cava reaches the heart

$37 \quad$ Height of origin of aorta

40 Height of bifurcation of brachiocephalic artery

41 Location of bifuraction of brachiocephalic artery into right common carotid and subclavian arteries

42 Height of bifurcation of left common carotic artery

43 Height of separation of left subclavian artery

44, 45 Height of junction of internal carotid and subclavian veins on each side

46 Height of union of brachiocephalic veins on both side

47 Height at which the superior vena cava reaches the heart

48 Point of origin of pulmonary artery

49 Height of union of azygos vein with superior vena cava

50-52 Height of entry of pulmonary artery into hilum

53-56 Height of entry of pulmonary vein into hilum

14, 15 Upper borders of lung

16, 17 Lower borders of lung

38 Apex of aortic arch

39 Left end of aortic arch 


\section{References}

1) Hartman \& Straus: The Anatomy of the Rhesus Monkey. Baltimore, 1933.

2) L i n, K. C.: On the position of abdominalorgans in Macacus cyclopsis. Okajimas Fol. anat. jap., Bd. 27 (1955).

3) Naruse, M.; Fetalchange of the position of thoracic organs of Japanese (to be published).

4) Nozaki, K.: Anatomical studies on the trachea bronchien and bronchialbranches of Japanese. Igaku Kenkyu, Vol. 3, (1929), (japanese) 